\title{
Role of cGMP-dependent protein kinases for fear memory formation in the lateral amygdala Cindy Paul ${ }^{1}$, Florian Schöberl ${ }^{1}$, Pascal Weinmeister ${ }^{1}$, Vincenzo Micale ${ }^{2,3}$, Carsten Wotjak ${ }^{2}$, Franz Hofmann ${ }^{1}$ and Thomas Kleppisch*1
}

\author{
Address: ${ }^{1}$ Institut für Pharmakologie und Toxikologie der Technischen Universität München, München, Germany, ${ }^{2}$ Max-Planck-Institut für \\ Psychiatrie, München, Germany and ${ }^{3}$ Department of Experimental and Clinical Pharmacology, University of Catania Medical School, 95125 \\ Catania, Italy \\ Email: Thomas Kleppisch* - kleppisch@ipt.med.tu-muenchen.de \\ * Corresponding author
}

from 4th International Conference of cGMP Generators, Effectors and Therapeutic Implications

Regensburg, Germany. 19-21 June 2009

Published: II August 2009

BMC Pharmacology 2009, 9(SuppI I):S2I doi:I0.I I86/I47I-22I0-9-SI-S2 I

This abstract is available from: http://www.biomedcentral.com/I47I-22I0/9/SI/S2I

(c) 2009 Paul et al; licensee BioMed Central Ltd.

Fear memory formation critically relies on the function of the lateral amygdala (LA) and changes in synaptic transmission of its sensory inputs. There is evidence that signaling through NO/cGMP in the amygdala contributes to these processes [1-3]. The cGMP-dependent protein kinases (cGK) type I and II serve as universal effectors of the NO/cGMP signaling cascade. Recently, we established a functional role of cGKI for synaptic plasticity and fear memory consolidation in the amygdala. First, we demonstrated that the CGKI $\beta$ isoform is highly expressed in the LA. Furthermore, we showed that cGKI-deficient mice revealed deficits in amygdala-dependent fear memory consolidation. In contrast, short-term memory and hippocampus-dependent memory was intact in these mice. In line with the behavioral phenotype of impaired auditory long-term memory, we found reduced long-term potentiation (LTP) in the LA of cGKI-deficient mice, which is considered as a cellular mechanism for learning induced synaptic plasticity. Unlike cGKI-deficient mice, cGKII-knockout mice lack these phenotypes. These results clearly suggest a crucial role of cGKI for consolidation of amygdala-dependent fear memory, a process by which newly learned information is stabilized into long-term memory (LTM). It is a well known fact that memory consolidation strictly depends on transcriptional and translational processes which is also proved essential for amygdala-dependent fear memory consolidation $[4,5]$. A functional link between cGKI activity and gene transcription could already be demonstrated in vitro [6]. The upcoming question is if cGKI-induced transcription also takes place in amygdala neurons recruited during memory formation. Preliminary data indicate a role for cGKI in cAMP-response element binding protein (CREB) signaling in the LA, a prominent transcription factor involved in learning and memory.

\section{References}

I. Chien WL, Liang KC, Teng CM, Kuo SC, Lee FY, Fu WM: Enhancement of long-term potentiation by a potent nitric oxide-guanylyl cyclase activator, 3-(5-hydroxymethyl-2-furyl)-Ibenzyl-indazole. Mol Pharmacol 2003, 63:1322-1328.

2. Chien WL, Liang KC, Teng CM, Kuo SC, Lee FY, Fu WM: Enhancement of learning behaviour by a potent nitric oxide-guanylate cyclase activator YC-I. Eur J Neurosci 2005, 21:1679-1688.

3. Schafe GE, Bauer EP, Rosis S, Farb CR, Rodrigues SM, LeDoux JE: Memory consolidation of Pavlovian fear conditioning requires nitric oxide signaling in the lateral amygdala. Eur J Neurosci 2005, 22:20I-2II.

4. Schafe GE, LeDoux JE: Memory consolidation of auditory pavlovian fear conditioning requires protein synthesis and protein kinase A in the amygdala. J Neurosci 2000, 20:RC96.

5. Duvarci S, Nader K, LeDoux JE: De novo mRNA synthesis is required for both consolidation and reconsolidation of fear memories in the amygdala. Learn Mem 2008, 15:747-755.

6. Gudi T, Huvar I, Meinecke M, Lohmann SM, Boss GR, Pilz RB: Regulation of gene expression by cGMP-dependent protein kinase. Transactivation of the c-fos promoter. I Biol Chem 1996, 27 I:4597-4600. 